\title{
APLIKASI KOMPOS TANDAN KOSONG KELAPA SAWIT DAN HORMON TANAMAN UNGGUL TERHADAP PERTUMBUHAN TANAMAN ANTHURIUM (Anthurium sp)
}

\section{Aplication of Compost Bunches of Oil Palm and Plant Hormone Superior to Plant Growth Anthurium (Anthurium sp)}

\author{
T. Rosmawaty dan Samsul Kurniawan \\ Program Studi Agroteknologi, Fakultas Pertanian, Universitas Islam Riau \\ Jl. Kaharuddin Nasution No. 113 P. Marpoyan, Pekanbaru, Riau 28284, Indonesia. \\ [Diterima Januari 2017; Disetujui Juli 2017]
}

\begin{abstract}
This research aims to examine the effect of compost bunches of oil palm and plant hormone superior on growt of anthurium plant. The research was conducted at the experiment farm of faculty of agriculture Riau Islamic university during 4 months, starting from April to July 2015. The completely randomized design was used by using 2 factors, the first factor was compost bunches of oil palm, consisting of $0,15,30,45 \mathrm{~g} / \mathrm{polybag}$, the second factor was plant hormone superior consisting of $0,2,4,6$ milli/liter. The parameters observed the number of leaves per plant, total leaf area, relative growth rate, net assimilation rate, root volume. The results showed that interactinally has effect on number of leaves per plant and root volume the best treatment of compost bunches of oil palm $30 \mathrm{~g} /$ ploybag and plant hormone superior 4 milli/liter. Application of compost bunches of oil palm affects all observation parameter, the best treatment $30 \mathrm{~g} /$ polybag. Application of plant hormone superior affects all observation parameter, the best treatment 4 mili/liter.
\end{abstract}

Keywords: Compost, Bunches of Oil Palm, Plant Hormone Superior, Anthurium

\begin{abstract}
ABSTRAK
Tujuan penelitian ini adalah untuk mengetahui pengaruh pemberian kompos tandan kosong kelapa sawit (Taspu) dan hormon tanaman unggul terhadap pertumbuhan Anthurium. Penelitian dilaksanakan di Kebun Percobaan Fakultas Pertanian Universitas Islam Riau Selama 4 bulan dimulai dari bulan April sampai Juli 2015. Penelitian ini menggunakan Rancangan Acak Lengkap yang terdiri dari 2 faktor, faktor pertama adalah Kompos Tandan Kosong Kelapa Sawit (T) yang terdiri dari $0,15,30$ dan $45 \mathrm{~g} /$ polybag. Faktor kedua adalah hormon tanaman unggul yang terdiri dari $0,2,4$ dan $6 \mathrm{ml} / \mathrm{l}$. Parameter yang diamati adalah jumlah daun per tanaman, luas daun total, Laju pertumbuhan relatif, laju asimilasi bersih dan volume akar. Hasil penelitian menunjukkan bahwa interaksi kedua perlakuan berpengaruh terhadap jumlah daun per tanaman dan volume akar, perlakuan terbaik pemberian kompos tandan kosong kelapa sawit (taspu) $30 \mathrm{~g} /$ polybag dan hormon tanaman unggul $4 \mathrm{ml} / \mathrm{l}(\mathrm{P} 2 \mathrm{H} 2)$. Aplikasi kompos tandan kosong kelapa sawit nyata terhadap semua pengamatan, perlakuan terbaik pada pemberian kompos tandan kosong kelapa sawit $30 \mathrm{~g} /$ tanaman (P2). Aplikasi hormon tanaman unggul nyata terhadap semua parameter pengamatan, perlakuan terbaik pada pemberian hormon tanaman unggul $4 \mathrm{ml} / \mathrm{l}(\mathrm{H} 2)$.
\end{abstract}

Kata Kunci: Kompos, Taspu, Hormon Tanaman Unggul, Anthurium.

\section{PENDAHULUAN}

Anthurium merupakan salah satu tanaman hias yang semakin popular. Hal ini disebabkan karena bentuk daun dan warna bunganya yang beranekaragam dan sangat menarik. Anthurium merupakan komoditi yang memiliki nilai ekonomis yang cukup tinggi, penanamannya tidak hanya sebagai tanaman hias atau kegemaran saja tetapi sudah merupakan komoditi sebagai sumber pendapatan, hal ini dikarenakan harga jual anthurium cukup mahal sebanding dengan keindahan dan keunikannya.

Daya tarik utama dari anthurium adalah bentuk daunnya yang indah, unik, dan 
bervariasi. Daun umumnya berwarna hijau tua dengan urat dan tulang daun besar dan menonjol. Sehingga membuat sosok tanaman ini tampak kekar namun tetap memancarkan keanggunan tatkala dewasa. Tidak heran bila tanaman ini memiliki kesan mewah dan eksklusif. Dimasa lalu, anthurium banyak menjadi hiasan taman dan istana kerajaankerajaan di Jawa. Namun, untuk menciptakan pertumbuhan optimal dalam kegiatan budidaya tanaman anthurium memerlukan perlakuan khusus. Selain media tanam yang sesuai, tanaman anthurium juga memerlukan zat hara untuk pertumbuhannya, hara tersebut dapat langsung diberikan ke media tanam, salah satunya yaitu dengan menambahkan bahan organik seperti pupuk taspu.

Kompos tankos merupakan kompos yang terbuat dari bahan dasar tandan kosong (tankos) kelapa sawit yang siap pakai. Kompos tankos mengandung unsur hara $\mathrm{N}, \mathrm{P}, \mathrm{K}, \mathrm{Mg}$ dan $\mathrm{Ca}$ yang cepat diserap tanaman. Selain penambahan hara yang langsung ke media tanam, perlu adanya pemberian hormon melalui daun agar dapat menunjang pertumbuhannya menjadi lebih baik dimana hormon yang telah beredar dipasaran yaitu hormon tanaman unggul.

Dengan pemberian pupuk taspu pada media tanam serta pemberian hormon tanaman unggul sebagai penyeimbang ketersediaan unsur hara dan juga sebagai ZPT diharapkan dapat menunjang pertumbuhan tanaman anthurium menjadi lebih baik. Berdasarkan permasalahan tersebut penelitian ini bertujuan untuk menguji "Aplikasi Kompos Tandan Kosong Kelapa Sawit (Taspu) dan Hormon Tanaman Unggul Pada Tanaman Anthurium (Anthurium sp)".

\section{METODE PENELITIAN}

Penelitian ini akan dilaksanakan di kebun percobaan Fakultas Pertanian Universitas Islam Riau, Jalan Kaharuddin Nasution KM 11, No. 113 Marpoyan, Kelurahan Simpang Tiga, Kecamatan Bukit Raya, Kota Pekanbaru. Penelitian ini berlangsung selama 4 bulan. Di mulai dari bulan April sampai Bulan Juli 2015.

Bahan yang di gunakan dalam penelitian ini adalah: bibit Anthurium (gelombang cinta), kompos tandan kosong kelapa sawit (Taspu), hormon tanaman unggul, pupuk NPK Mutiara
16:16:16, Decis 25 EC, Dithane M-45, sekam bakar, tanah, kayu, dan polybag ukuran $25 \times 30$. Alat-alat yang digunakan dalam penelitian ini adalah cangkul, parang, gergaji, meteran, gembor, handsprayer, kamera, timbangan digital, martil, dan alat-alat tulis.

Rancangan yang digunakan dalam penelitian ini adalah Rancangan Acak Lengkap (RAL) secara faktorial yang terdiri dari dua faktor. Faktor pertama adalah Pemberian Kompos tandan kosong kelapa sawit/Taspu (P) dan faktor kedua pemberian Hormon Tanaman Unggul (H).

Faktor pertama terdiri dari 4 taraf perlakuan dan faktor kedua terdiri dari 4 taraf perlakuan, sehingga terdapat 16 kombinasi perlakuan dengan 3 kali ulangan. Dengan demikian penelitian ini terdiri dari 48 plot percobaan. Setiap plot terdiri dari 8 tanaman dan 6 tanaman dijadikan sebagai sampel.

\section{HASIL DAN PEMBAHASAN}

\section{Jumlah Daun}

Hasil pengamatan terhadap jumlah daun per tanaman setelah dilakukan analisis ragam menunjukkan bahwa baik interaksi maupun pengaruh utama pemberian kompos tandan kelapa sawit dan hormon tanaman unggul nyata terhadap parameter jumlah daun tanaman anthurium. Hasil uji lanjut BNJ pada taraf 5\% dapat dilihat pada Tabel 1.

Kompos tandan kosong kelapa sawit (taspu) merupakan pupuk yang berbahan baku dari tandan kosong kelapa sawit yang telah dipermentasi tanpa adanya penambahan starter dan bahan kimia, pupuk taspu merupakan bahan organik yang dapat memperkaya unsur hara di dalam tanah selain itu juga dapat memperbaiki kondisi tanah menjadi lebih subur, sehingga unsur hara didalam tanah dapat lebih tersedia dan dapat dengan mudah dimanfaatkan oleh tanaman, hal ini terlihat dari penelitian yang telah dilaksanakan dimana dengan adanya pemberian pupuk taspu jumlah daun anthurium yang dihasilkan lebih banyak dari perlakuan tanpa pemberian kompos tandan kosong kelapa sawit. 
Aplikasi Kompos Tandan Kosong Kelapa Sawit dan Hormon Tanaman Unggul terhadap Pertumbuhan

Tanaman Anthurium (Anthurium sp)

Tabel 1. Rerata Jumlah Daun Anthurium dengan Perlakuan Pemberian Kompos Tandan Kosong Kelapa Sawit (Taspu) dan Hormon Tanaman Unggul (Helai)

\begin{tabular}{|c|c|c|c|c|c|}
\hline \multirow{2}{*}{$\begin{array}{c}\text { Pupuk Taspu } \\
\text { (g/tanaman) }\end{array}$} & \multicolumn{4}{|c|}{ Hormon Tanaman Unggul (ml/l) } & \multirow{2}{*}{ Rerata } \\
\hline & H0 (0) & H1 (2) & $\mathrm{H} 2(4)$ & H3 (6) & \\
\hline $\mathrm{P} 0(0)$ & $7.17 \mathrm{~g}$ & $8.58 \mathrm{ef}$ & 9.67 cde & $9.33 \mathrm{cdef}$ & $8.69 \mathrm{c}$ \\
\hline P1 (15) & $8.42 \mathrm{f}$ & $8.83 \mathrm{def}$ & $10.00 \mathrm{~cd}$ & 9.25 cdef & $9.13 \mathrm{~b}$ \\
\hline P2 (30) & 9.17 cdef & $9.92 \mathrm{~cd}$ & $11.83 \mathrm{a}$ & $10.17 \mathrm{bc}$ & $10.27 \mathrm{a}$ \\
\hline P3 (45) & $9.00 \mathrm{def}$ & $9.33 \mathrm{cdef}$ & $11.25 \mathrm{ab}$ & $10.25 \mathrm{bc}$ & $9.96 \mathrm{a}$ \\
\hline Rerata & $8.44 \mathrm{~d}$ & $9.17 \mathrm{c}$ & $10.69 \mathrm{a}$ & $9.75 \mathrm{~b}$ & \\
\hline
\end{tabular}

Angka-angka pada baris dan kolom yang diikuti huruf kecil yang sama menunjukan tidak berbeda nyata menurut uji lanjut BNJ pada taraf $5 \%$.

Berdasarkan Tabel 1 pemberian kompos tandan kosong kelapa sawit $30 \mathrm{~g} /$ tanaman yang dikombinasikan dengan hormon tanaman unggul $4 \mathrm{ml} / \mathrm{l}$ menghasilkan jumlah daun terbanyak, hal ini diduga dengan dosis tersebut sudah mampu memperbaiki sifat fisik, kimia dan biologi tanah, hal ini sependapat dengan Kaderi (2004) mengemukakan pemberian bahan organik seperti kompos dapat membantu akar tanaman menembus tanah lebih dalam dan luas sehingga tanaman lebih mampu menyerap unsur hara dan air dalam jumlah banyak.

Lingga (2005) mengemukakan bahwa pupuk organik sangat besar peranannya dalam usaha memperbaiki ketahanan tanah terhadap terjadinya erosi dan memperbaiki struktur tanah. Asripa (2000) mengemukakan bahwa program pemupukan bertujuan meningkatkan kesuburan tanah dan kegiatan biologi tanah dengan cara menambahkan bahan organik dalam jumlah yang memadai.

Kemudian dikombinasikan dengan hormon tanaman ungguk $4 \mathrm{cc} / \mathrm{l}$, dapat lebih mengaktifkan hormon dalam tanaman. Yahya dalam Rosmawaty (2003) mengemukakan bahwa pemupukan lewat daun dipandang lebih efektif karena pemupukan yang di berikan lewat daun sudah selesai terurai, sehingga mudah di serap oleh tanaman. Disamping itu respon tanaman terhadap pemberian pupuk akan meningkat bila menggunakan jenis, dosis dan waktu serta pemberian pupuk yang tepat.

\section{Total Luas Daun $\left(\mathrm{cm}^{2}\right)$}

Data hasil pengamatan terhadap total luas daun setelah dilakukan analisis sidik ragam, menunjukkan bahwa interaksi pemberian kompos tandan kosong kelapa sawit dan hormon tanaman unggul tidak memberikan pengaruh nyata, namun pengaruh utama pemberian kompos tandan kosong kelapa sawit dan hormon tanaman unggul memberikan pengaruh terhadap parameter total luas daun tanaman anthurium. Hasil pengamatan total luas daun tanaman anthurium setelah di uji lanjut BNJ pada taraf 5\% dapat dilihat pada Tabel 2.

Pengaruh utama pemberian pupuk taspu pada tanaman anthurium memberikan pengaruh terhadap total luas daun, dimana pemberian pupuk taspu $30 \mathrm{~g} / \operatorname{tanaman}$ (P2) merupakan perlakuan terbaik dengan total luas daun 210.70 $\mathrm{cm} 2$, kemudian diikuti oleh perlakuan pemberian pupuk taspu $45 \mathrm{~g} / \operatorname{tanaman}$ (P3) dengan total luas daun $186.18 \mathrm{~cm} 2$, pemberian pupuk taspu $15 \mathrm{~g} /$ tanaman (P1) yaitu 167.30 $\mathrm{cm} 2$, dan luas daun terendah dihasilkan oleh perlakuan kontrol (P0) yaitu $125.98 \mathrm{~cm} 2$. Dimana perlakuan P2 berbedanyata dengan semua perlakuan lainnya, perlakuan P3 tidak berbedanyata dengan perlakuan P1 dan berbedanyata dengan perlakuan $\mathrm{P} 0$.

Luasnya total luas daun yang dihasilkan oleh perlakuan pemberian pupuk taspu 30 g/tanaman, dikarenakan pupuk taspu yang diberikan telah dapat memberikan respon yang baik terhadap perbaikan kondisi tanah yang digunakan pada media anthurium, tanah menjadi lebih subur sehingga akar tanaman anthurium lebih mudah dalam menyerap unsur hara, maka dengan terpenuhinya hara bagi tanaman proses metabolisme akan berlangsung dengan baik sehingga pertumbuhan dan perkembangan tanaman juga akan berlangsung 
Tabel 2. Rerata Total Luas Daun Anthurium dengan Pemberian Kompos Tandan Kosong Kelapa Sawit (Taspu) dan Hormon Tanaman Unggul $\left(\mathrm{cm}^{2}\right)$

\begin{tabular}{cccccc}
\hline \multirow{2}{*}{$\begin{array}{c}\text { Pupuk Taspu } \\
\text { (g/tanaman) }\end{array}$} & \multicolumn{3}{c}{ Hormon Tanaman Unggul (ml/l) } & \multirow{2}{*}{ Rerata } \\
\cline { 2 - 5 } & $\mathrm{H} 0(0)$ & $\mathrm{H} 1(2)$ & $\mathrm{H} 2(4)$ & $\mathrm{H} 3(6)$ & \\
\hline P0 (0) & 92.78 & 110.66 & 165.30 & 135.16 & $125.98 \mathrm{c}$ \\
P1 (15) & 126.44 & 157.99 & 209.04 & 175.74 & $167.30 \mathrm{~b}$ \\
P2 (30) & 181.92 & 206.89 & 242.52 & 211.46 & $210.70 \mathrm{a}$ \\
P3 (45) & 152.72 & 176.47 & 223.13 & 192.41 & $186.18 \mathrm{~b}$ \\
\hline Rerata & $138.47 \mathrm{c}$ & $163.00 \mathrm{~b}$ & $210.00 \mathrm{a}$ & $178.69 \mathrm{~b}$ & \\
\hline
\end{tabular}

Angka-angka pada baris dan kolom yang diikuti huruf kecil yang sama menunjukan tidak berbeda nyata menurut uji lanjut BNJ pada taraf $5 \%$.

dengan baik, sehingga luas daun juga akan bertambah.

Berdasarkan data pada Tabel 2 menunjukkan bahwa pengaruh utama pemberian hormon tanaman unggul pada tanaman anthurium memberikan pengaruh terhadap total luas daun, dimana pemberian hormon tanaman unggul $4 \mathrm{ml} / \mathrm{l}$ (P2) mengahasilkan luas daun terluas yaitu $210.00 \mathrm{~cm} 2$, berbedanyata dengan pemberian hormon tanaman unggul $6 \mathrm{ml} / \mathrm{l}(\mathrm{P} 3)$ dengan luas daun $178.69 \mathrm{~cm} 2$ dan pemberian hormon tanaman unggul $2 \mathrm{ml} / \mathrm{l}$ (P1) yaitu $163.00 \mathrm{~cm} 2$, dan luas daun terendah dihasilkan oleh perlakuan kontrol (P0) yaitu $138.47 \mathrm{~cm} 2$.

Tingginya total luas daun yang dihasilkan pada perlakuan P2 hal ini dikarenakan pada perlakuan tersebut merupakan dosis yang tepat sehingga hormon tanaman unggul yang diberikan dapat memacu pertumbuhan tanamana anthurium sehingga dapat menghasilkan total luas daun tertinggi. Hormon tanaman unggul merupakan pupuk yang mengandung zpt seperti asam giberelin, asam asetik indol dan zeatin. Hardjadji (2009) mengemukakan bahwa peran sitokinin dan giberelin akan saling mendukung dalam menstimulus proses regulasi genetik dan yang kemudian berfungsi untuk meningkatkan pertumbuhan dan perkembangan tanaman.

Sujimin (2011) mengemukakan bahwa hormon tanaman unggul merupakan pupuk yang terbuat dari sari tumbuhan alami (herbal), seperti: tumbuh-tumbuhan sirih, madu, lemak hewan dan beberapa zat lainnya, adapun manfaat dan kelebihan hormon tanaman unggul ini menjadikan tanaman mempunyai daya tahan dan tumbuh melebihi perkembangan standar, dapat mempercepat pertumbuhan daun, mempercepat perkembangan batang dalam melakukan pembelahan sel sehingga cepat besar, mempercepat pertumbuhan akar baru dan lebih kokoh serta mempercepat keluarnya tunastunas dan anakan baru.

Dalam berbagai penelitian, kandungan nutrisi pupuk tandan kosong cukup tinggi terutama merehabilitasi tanah. Tercatat kandungan nutrisi kompos dari tandan kosong antara lain: $\mathrm{N}>1.5 \%, \quad \mathrm{P}>0.3 \%, \quad \mathrm{~K}>2.00 \%$, $\mathrm{Ca}>0.72 \%, \mathrm{Mg}>0.4 \%$, bahan organik $>50 \%$, $\mathrm{C} / \mathrm{N}$ 15,03\% dan kadar air 45-50\% (Anggar. 2014).

Pemberian pupuk taspu pada tanaman anthurium telah dapat memberikan pengaruh yang baik dibandingkan dengan tanpa pemberian pupuk taspu, hal ini dikarenakan pupuk taspu merupakan bahan organik yang dapat memperbaiki kondisi tanah menjadi lebih subur. Bahan organik yang diberikan dapat lebih mengaktifkan mikroorganisme dalam tanah sehingga proses dekomposisi dan mineralisasi akan meningkat. Lingga (2005) mengemukakan bahwa pupuk organik sangat besar peranannya dalam usaha memperbaiki ketahanan tanah terhadap terjadinya erosi dan memperbaiki struktur tanah.

\section{Laju Pertumbuhan Relatif/LPR (mg/hari)}

Hasil pengamatan terhadap laju pertumbuhan relatif setelah dilakukan analisis menunjukkan bahwa interaksi pemberian kompos tandan kosong kelapa sawit dan hormon tanaman unggul tidak memberikan pengaruh, namun pengaruh utama kompos tandan kosong kelapa sawit dan hormon tanaman unggul memberikan pengaruh terhadap 
Aplikasi Kompos Tandan Kosong Kelapa Sawit dan Hormon Tanaman Unggul terhadap Pertumbuhan Tanaman Anthurium (Anthurium sp)

Tabel 3. Rerata Laju Pertumbuhan Relatif Anthurium dengan Pemberian Kompos Tandan Kosong Kelapa Sawit (Taspu) dan Hormon Tanaman Unggul (mg/hari)

\begin{tabular}{ccccccc}
\hline HST & $\begin{array}{c}\text { Pupuk Taspu } \\
\text { (g/tanaman) }\end{array}$ & \multicolumn{4}{c}{ Hormon Tanaman Unggul (ml/l) } & Rerata \\
\cline { 3 - 6 } $28-21$ & H0 $(0)$ & H1 $(2 \mathrm{cc} / \mathrm{l})$ & $\mathrm{H} 2(4 \mathrm{cc} / \mathrm{l})$ & $\mathrm{H} 3(6 \mathrm{cc} / \mathrm{l})$ & \\
& P0 (kontrol) & 0.109 & 0.131 & 0.181 & 0.163 & $0.146 \mathrm{c}$ \\
& P1 (15) & 0.129 & 0.157 & 0.195 & 0.179 & $0.165 \mathrm{~b}$ \\
& P2 (30) & 0.159 & 0.178 & 0.223 & 0.218 & $0.195 \mathrm{a}$ \\
& P3 (45) & 0.144 & 0.164 & 0.201 & 0.187 & $0.174 \mathrm{~b}$ \\
\hline \multirow{2}{*}{$42-35$} & Rerata & $0.135 \mathrm{c}$ & $0.158 \mathrm{~b}$ & $0.200 \mathrm{a}$ & $0.187 \mathrm{a}$ & \\
& P0 (kontrol) & 0.246 & 0.267 & 0.339 & 0.285 & $0.284 \mathrm{~d}$ \\
& P1 (15) & 0.273 & 0.318 & 0.389 & 0.352 & $0.333 \mathrm{c}$ \\
& P2 (30) & 0.343 & 0.376 & 0.432 & 0.396 & $0.387 \mathrm{a}$ \\
& P3 (45) & 0.310 & 0.344 & 0.409 & 0.367 & $0.358 \mathrm{~b}$ \\
\hline & Rerata & $0.293 \mathrm{~d}$ & $0.326 \mathrm{c}$ & $0.392 \mathrm{a}$ & $0.350 \mathrm{~b}$ & \\
\hline
\end{tabular}

Angka-angka pada baris dan kolom yang diikuti huruf kecil yang sama menunjukan tidak berbeda nyata menurut uji lanjut BNJ pada taraf $5 \%$.

parameter laju pertumbuhan relatif tanaman anthurium. Rerata hasil pengamatan laju pertumbuhan relatif tanaman anthurium setelah di uji lanjut BNJ pada taraf 5\% disajikan pada Tabel 3.

Berdasarkan Tabel 3 memperlihatkan bahwa laju pertumbuhan relatif 28-21 tertinggi dihasilkan oleh perlakuan pemberian pupuk taspu $30 \mathrm{~g} /$ tanaman dengan nilai LPR 0.195 $\mathrm{mg} / \mathrm{hari}$, kemudian diikuti oleh pemberian pupuk taspu $45 \mathrm{~g} /$ tanaman yaitu $0.174 \mathrm{mg} /$ hari, pemberian pupuk taspu $15 \mathrm{~g} / \operatorname{tanaman}(\mathrm{P} 1)$ yaitu $0.165 \mathrm{mg} / \mathrm{hari}$ dan nilai LPR terendah dihasilkan oleh perlakuan kontrol (P0) yaitu $0.146 \mathrm{mg} / \mathrm{hari}$. Dimana perlakuan P2 berbedanyata dengan semua perlakuan lainnya, perlakuan P3 tidak berbedanyata dengan perlakuan P1 dan berbedanyata dengan perlakuan $\mathrm{P} 0$.

Laju pertumbuhan relatif pada 42-35 hari menunjukkan bahwa nilai LPR tertinggi dihasilkan oleh perlakuan pemberian pupuk taspu $30 \mathrm{~g} / \operatorname{tanaman}(\mathrm{P} 2)$ yaitu $0.387 \mathrm{mg} / \mathrm{hari}$, kemudian diikuti oleh pemberian pupuk taspu $45 \mathrm{~g} /$ tanaman yaitu $0.358 \mathrm{mg} / \mathrm{hari}$, pemberian pupuk taspu $15 \mathrm{~g} / \operatorname{tanaman}$ (P1) yaitu 0.333 $\mathrm{mg} /$ hari dan nilai LPR terendah terdapat pada perlakuan kontrol yaitu (P0) yaitu 0.284 $\mathrm{mg} /$ hari. perlakuan $\mathrm{P} 2$ berbedanyata dengan perlakuan lainnya dan perlakuan P3 berbedanyata dengan perlakuan P1 dan P0.
Tingginya nilai LPR yang dihasilkan oleh pemberian kompos tandan kosong kelapa sawit $30 \mathrm{~g} /$ tanaman baik pada pengamatan 28-21 hari dan 42-35 hari, hal ini dikarenakan dengan pemberian kompos tandan kosong kelapa sawit pada media tanaman anthurium telah dapat memberikan pengaruh yang baik terhadap pertumbuhan tanaman anthurium, kompos tandan kosong kelapa sawit merupakan kompos yang berbahan baku murni dari tandan kosong kelapa sawit sehingga merupakan bahan organik, pemberian bahan organik ke dalam tanah dapat memperbaiki kondisi tanah menjadi lebih subur, unsur hara dalam tanah lebih tersedia dan dapat diserap oleh akar tanaman dengan baik. Dengan terpenuhinya unsur hara maka proses fotosintesis akan berlangsung dengan baik, sehingga hasil bahan asimilasi akan lebih banyak tertumpuk dalam bagian tubuh tanaman.

Data pada Tabel 3 menunjukkan bahwa pengaruh utama pemberian hormon tanaman unggul memberikan pengaruh terhadap pengamatan laju pertumbuhan relatif 35-28 hari, dimana perlakuan terbaik terdapat pada pemberian hormon tanaman unggul $4 \mathrm{cc} / \mathrm{l}(\mathrm{H} 2)$ dengan nilai LPR $0.200 \mathrm{mg} / \mathrm{hari}$, kemudian diikuti oleh pemberian hormon tanaman unggul $6 \mathrm{cc} / \mathrm{l}$ (H3) yaitu $0.187 \mathrm{mg} / \mathrm{hari}$, pemberian hormon tanaman unggul $2 \mathrm{cc} / \mathrm{l}(\mathrm{H} 1)$ yaitu 0.158 $\mathrm{mg} /$ hari dan nilai LPR terendah terdapat pada perlakuan kontrol (H0) yaitu $0.135 \mathrm{mg} / \mathrm{hari}$. 
Laju pertumbuhan relatif tanaman anthurium pada 35-28 hari pada masing-masing taraf pengaruh utama pemberian hormon tanaman unggul memberikan pengaruh yang berbeda, dimana perlakuan terbaik terdapat pada pemberian hormon tanaman unggul $4 \mathrm{ml} / \mathrm{l}$ (H2) dengan nilai LPR $0.392 \mathrm{mg} / \mathrm{hari}$, kemudian diikuti oleh pemberian hormon tanaman unggul $6 \mathrm{ml} / \mathrm{l}(\mathrm{H} 3)$ yaitu $0.350 \mathrm{mg} / \mathrm{hari}$, pemberian hormon tanaman unggul $2 \mathrm{ml} / \mathrm{l}(\mathrm{H} 1)$ yaitu 0.326 $\mathrm{mg} / \mathrm{hari}$ dan nilai LPR 35-28 terendah terdapat pada perlakuan kontrol (H0) yaitu 0.293 $\mathrm{mg} /$ hari.

Tingginya nilai laju pertumbuhan relatif tanaman anthurium dengan pemberian hormon tanaman unggul $4 \mathrm{ml} / \mathrm{l}(\mathrm{H} 2)$ baik pada 21-14 maupun 35-28 hal ini dikarenakan pada dosis tersebut merupakan perlakuan yang tepat sehingga ZPT yang terkandung dalam hormon tanaman unggul mampu mengaktifkan hormon yang terkandung dalam jaringan tanaman, dengan demikian proses metabolisme dalam tubuh tanaman dapat berjalan dengan baik. Dwijoseputro (2002) mengemukakan bahwa zat stimulus pertumbuhan atau zat pengatur tumbuh yang biasa disebut ZPT pada umumnya berfungsi dan berperan merangsang pertumbuhan dan perkembangan tanaman lebih baik dari biasanya. Harjadji (2009) mengemukakan bahwa pengaruh pemberian hormon tumbuh sudah dapat dilihat dengan sangat cepat pada tahap awal pertumbuhan dan perkembangan tumbuhan yang secara kontinu akan memberikan pengaruh yang sama maksimal pada tahap pertumbuhan dan perkembangan tanaman selanjutnya.

\section{Laju Asimilasi Bersih/LAB}

Hasil pengamatan terhadap laju asimilasi bersih tanaman anthurium pada 28-21 dan 42-35 setelah dilakukan analisis sidik ragam, menunjukkan bahwa interaksi kompos tandan kosong kelapa sawit dan hormon tanaman unggul tidak memberikan pengaruh, namun pengaruh utama kompos tandan kosong kelapa sawit dan hormon tanaman unggul memberikan pengaruh terhadap parameter laju asimilasi bersih tanaman anthurium. Rerata hasil pengamatan laju asimilasi bersih tanaman anthurium setelah di uji lanjut BNJ pada taraf 5\% dapat dilihat pada Tabel 4.

Pemberian pupuk taspu memberikan pengaruh terhadap laju asimilasi bersih tanaman anthurium baik pada 28-21 maupun 42-35, nilai laju asimilasi bersih tertinggi pada 21-14 dihasilkan pada pemberian pupuk taspu 30 g/tanaman (P2) dengan nilai LAB 0.0019 $\mathrm{mg} / \mathrm{cm} 2 / \mathrm{hr}$, kemudian diikuti oleh pemberian pupuk taspu $45 \mathrm{~g} / \operatorname{tanaman}(\mathrm{P} 3)$ yaitu 0.0018 $\mathrm{mg} / \mathrm{cm} 2 / \mathrm{hr}$, pemberian pupuk kompos tandan

Tabel 4. Rerata Laju Asimilasi Bersih Anthurium dengan Pemberian Kompos Tandan Kosong Kelapa Sawit (Taspu) dan Hormon Tanaman Unggul (mg/ $\left./ \mathrm{cm}^{2} / \mathrm{hr}\right)$

\begin{tabular}{|c|c|c|c|c|c|c|}
\hline \multirow[b]{2}{*}{ HST } & \multirow{2}{*}{$\begin{array}{c}\text { Pupuk Taspu } \\
\text { (g/tanaman) }\end{array}$} & \multicolumn{4}{|c|}{ Hormon Tanaman Unggul (ml/l) } & \multirow{2}{*}{ Rerata } \\
\hline & & H0 (0) & H1 (2 cc/l) & $\mathrm{H} 2(4 \mathrm{cc} / \mathrm{l})$ & H3 (6 cc/l) & \\
\hline \multirow{5}{*}{$28-21$} & P0 (kontrol) & 0.0011 & 0.0013 & 0.0017 & 0.0016 & $0.0014 \mathrm{c}$ \\
\hline & P1 (15) & 0.0014 & 0.0015 & 0.0019 & 0.0018 & $0.0017 \mathrm{~b}$ \\
\hline & P2 (30) & 0.0016 & 0.0019 & 0.0022 & 0.0020 & $0.0019 \mathrm{a}$ \\
\hline & P3 (45) & 0.0015 & 0.0017 & 0.0021 & 0.0018 & $0.0018 \mathrm{a}$ \\
\hline & Rerata & $0.0014 \mathrm{~d}$ & $0.0016 \mathrm{c}$ & $0.0020 \mathrm{a}$ & $0.0018 \mathrm{~b}$ & \\
\hline \multirow{5}{*}{$42-35$} & P0 (kontrol) & 0.0012 & 0.0013 & 0.0020 & 0.0016 & $0.0015 \mathrm{~d}$ \\
\hline & P1 (15) & 0.0015 & 0.0016 & 0.0022 & 0.0018 & $0.0018 \mathrm{c}$ \\
\hline & P2 (30) & 0.0019 & 0.0021 & 0.0024 & 0.0023 & $0.0022 \mathrm{a}$ \\
\hline & P3 (45) & 0.0017 & 0.0019 & 0.0023 & 0.0020 & $0.0020 \mathrm{~b}$ \\
\hline & Rerata & $0.0016 \mathrm{c}$ & $0.0017 \mathrm{c}$ & $0.0022 \mathrm{a}$ & $0.0019 \mathrm{~b}$ & \\
\hline
\end{tabular}

Angka-angka pada baris dan kolom yang diikuti huruf kecil yang sama menunjukan tidak berbeda nyata menurut uji lanjut BNJ pada taraf 5\% 
kosong kelapa sawit $15 \mathrm{~g} / \mathrm{tanaman}(\mathrm{P} 1)$ yaitu $0.0017 \mathrm{mg} / \mathrm{cm} 2 / \mathrm{hr}$ dan nilai $\mathrm{LAB}$ terendah dihasilkan oleh perlakuan kontrol (P0) yaitu $0.0014 \mathrm{mg} / \mathrm{cm} 2 / \mathrm{hr}$. dimana perlakuan P2 tidak berbedanyata dengan perlakuan P3 dan berbedanyata dengan perlakuan $\mathrm{P} 1$ dan $\mathrm{P} 0$.

Sedangkan nilai laju asimilasi bersih 4235 pada masing-masing taraf pemberian kompos tandan kosong kelapa sawit memberikan pengaruh yang berbeda, dimana nilai LAB tertinggi dihasilkan oleh pemberian pupuk taspu $30 \mathrm{~g} / \operatorname{tanaman}(\mathrm{P} 2)$ yaitu 0.0022 $\mathrm{mg} / \mathrm{cm} 2 / \mathrm{hr}$, kemudian diikuti oleh pemberian pupuk taspu $45 \mathrm{~g} / \operatorname{tanaman}$ (P3) yaitu 0.0020 $\mathrm{mg} / \mathrm{cm} 2 / \mathrm{hr}$, pemberian pupuk taspu 15 g/tanaman (P1) yaitu $0.0018 \mathrm{mg} / \mathrm{cm} 2 / \mathrm{hr}$ dan nilai $\mathrm{LAB}$ terendah terdapat pada perlakuan kontrol (P0) yaitu $0.0015 \mathrm{mg} / \mathrm{cm} 2 / \mathrm{hr}$. Tingginya nilai laju asimilasi bersih yang dihasilkan oleh perlakuan pemberian pupuk taspu $30 \mathrm{~g} /$ tanaman (P2) baik pada 28-21 maupun 35-28 hal ini karena dengan pemberian pupuk taspu telah dapat memperbaiki kondisi tanah menjadi lebih subur, sehingga unsur hara dalam tanah lebih tersedia dan dapat dimanfaatkan oleh akar tanaman, sehingga proses metabolisme dalam tubuh tanaman dapat berlangsung dengan baik. Dengan demikian dapat mendukung pertumbuhan tamanan kearah yang lebih baik dan asimilat dalam jaringan tanaman akan lebih banyak sehingga akan mempengaruhi laju asimilasi bersih pada tanaman.

Laju pertumbuhan tanaman dipengaruhi oleh laju asimilasi bersih dan indeks luas daun. Laju asimilasi bersih tinggi dan indeks luas daun optimum akan meningkatkan laju pertumbuhan tanaman, dengan banyaknya cahaya matahari diterima tanaman maka tanaman memberikan respon dengan memperbanyak jumlah helaian daun, sehingga semakin banyak karbohidrat dihasilkan dalam proses fotosintesis sehingga mempercepat pertumbuhan dan perkembangan tanaman (Gardner et al., 1991).

Pertumbuhan tanaman adalah penimbunan bahan kering tanaman per satuan luas per satuan waktu. Bahan kering tanaman merupakan gambaran dari translokasi hasil fotosintesis kesluruh bagian tanaman sehingga dapat dikatakan laju tumbuh tanaman sangat ditentukan oleh luas daun tanaman yang mampu mengintersepsi sinar matahari secara maksimum dan laju fotosintesis tanaman selanjutnya.
Pertumbuhan suatu tanaman yang berlangsung dengan baik maka akan mampu menghasilkan bahan organik yang lebih banyak dan tersimpan dalam jaringan tanaman, yang pada akhirnya biomassa tanaman juga akan bertambah. Biomassa tanaman merupakan parameter yang sangat sering digunakan untuk menggambarkan dan mempelajari pertumbuhan tanaman.

Pengaruh utama pemberian hormon tanaman unggul terhadap laju asimilasi bersih pada 28-21 pada masing-masing taraf memberikan pengaruh yang berbeda, perlakuan terbaik dihasil oleh pemberian hormon tanaman unggul $4 \mathrm{ml} / \mathrm{l}(\mathrm{H} 2)$ dengan nilai LAB 0.0020 $\mathrm{mg} / \mathrm{cm} 2 / \mathrm{hr}$, kemudian diikuti oleh pemberian hormon tanaman unggul $6 \mathrm{ml} / \mathrm{l}$ (H3) yaitu $0.0018 \mathrm{mg} / \mathrm{cm} 2 / \mathrm{hr}$, pemberian hormon tanaman unggul $2 \mathrm{ml} / \mathrm{l}$ (H1) yaitu $0.0016 \mathrm{mg} / \mathrm{cm} 2 / \mathrm{hr}$ dan nilai LAB paling rendah dihasilkan oleh perlakuan kontrol $(\mathrm{H} 0)$ yaitu $0.0014 \mathrm{mg} / \mathrm{cm} 2 / \mathrm{hr}$.

Nilai laju asimilasi bersih pada 35-28 dengan pemberian hormon tanaman unggul menunjukkan bahwa pemberian hormon tanaman unggul $4 \mathrm{ml} / \mathrm{l}(\mathrm{H} 2)$ menghasilkan perlakaun terbaik dengan nilai LAB 0.0022 $\mathrm{mg} / \mathrm{cm} 2 / \mathrm{hr}$, kemudian diikuti oleh pemberian hormon tanaman unggul $6 \mathrm{ml} / \mathrm{l}(\mathrm{H} 3)$ yaitu $0.0019 \mathrm{mg} / \mathrm{cm} 2 / \mathrm{hr}$, pemberian hormon tanaman $2 \mathrm{ml} / \mathrm{l}(\mathrm{H} 1) \quad 0.0017 \mathrm{mg} / \mathrm{cm} 2 / \mathrm{hr}$ dan perlakuan kontrol merupakan perlakuan yang menghasilkan nilai LAB terendah yaitu 0.0016 $\mathrm{mg} / \mathrm{cm} 2 / \mathrm{hr}$. dimana perlakuan $\mathrm{H} 2$ dan $\mathrm{H} 3$ berbedanyata dengan semua perlakuan lainnya dan perlakuan $\mathrm{H} 1$ tidak berbedanyata dengan perlakuan $\mathrm{H} 0$.

Hormon tanaman unggul merupakan perpaduan antara pupuk dan zat pengatur tumbuh yang menjadikan tanaman mempunyai daya tahan mempunyai kemampuan tumbuh yang melebihi perkembangan standar. Hal ini terutama terlihat pada daun jadi lebih lebar dan subur, tunas akan bermunculan lebih banyak, batang akan mengalami pemekaran sel-selnya, akar akan berkembang pesat (Desatiga, 2009).

\section{Volume Akar}

Hasil pengamatan terhadap volume akar tanaman anthurium setelah dilakukan analisis sdidik ragam menunjukkan bahwa baik interaksi maupun pengaruh utama pemberian pupuk taspu dan hormon tanaman unggul memberikan 
pengaruh terhadap parameter volume akar sebagai alternatif pupuk organik juga akan

Tabel 5. Rerata Volume Akar Anthurium dengan Pemberian Kompos Tandan Kosong Kelapa Sawit (Taspu) dan Hormon Tanaman Unggul (ml)

\begin{tabular}{cccccc}
\hline \multirow{2}{*}{$\begin{array}{c}\text { Pupuk Taspu } \\
\text { (g/tanaman) }\end{array}$} & \multicolumn{4}{c}{ Hormon Tanaman Unggul (ml/l) } & \multirow{2}{*}{ Rerata } \\
\cline { 2 - 5 } & $\mathrm{H} 0(0)$ & $\mathrm{H} 1(2)$ & $\mathrm{H} 2(4)$ & $\mathrm{H} 3(6)$ & \\
\hline P0 (0) & $16.33 \mathrm{k}$ & $18.67 \mathrm{j}$ & $26.33 \mathrm{efg}$ & $23.67 \mathrm{hi}$ & $21.25 \mathrm{~d}$ \\
P1 (15) & $20.67 \mathrm{j}$ & $23.33 \mathrm{i}$ & $28.33 \mathrm{cde}$ & $26.00 \mathrm{fgh}$ & $24.58 \mathrm{c}$ \\
P2 (30) & $24.67 \mathrm{ghi}$ & $27.67 \mathrm{def}$ & $33.67 \mathrm{a}$ & $30.33 \mathrm{bc}$ & $29.08 \mathrm{a}$ \\
P3 (45) & $23.33 \mathrm{i}$ & $26.33 \mathrm{efg}$ & $31.33 \mathrm{~b}$ & $29.67 \mathrm{bcd}$ & $27.67 \mathrm{~b}$ \\
\hline Rerata & $21.25 \mathrm{~d}$ & $24.00 \mathrm{c}$ & $29.92 \mathrm{a}$ & $27.42 \mathrm{~b}$ & \\
\hline
\end{tabular}

Angka-angka pada baris dan kolom yang diikuti huruf kecil yang sama menunjukan tidak berbeda nyata menurut uji lanjut BNJ pada taraf $5 \%$.

tanaman anthurium. Rerata hasil pengamatan volume akar tanaman anthurium setelah di uji lanjut BNJ pada taraf 5\% dapat dilihat pada Tabel 5.

Interaksi pemberian pupuk taspu dan hormon tanaman unggul memberikan pengaruh teradap volume akar tanaman anthurium, dimana kombinasi perlakuan terbaik terdapat pada kombinasi perlakuan pemberian pupuk taspu $30 \mathrm{~g} /$ tanaman dan hormon tanaman unggul $4 \mathrm{ml} / \mathrm{l}(\mathrm{P} 2 \mathrm{H} 2)$ dengan volume akar 33.67 $\mathrm{ml}$, nilai volume akar terendah terdapat pada perlakuan tanpa pemberian kompos tandan kosong kelapa sawit dan tanpa pemberian hormon tanaman unggul $(\mathrm{POHO})$ yaitu 16.33 $\mathrm{cm} 3$.

Berpengaruhnya kombinasi perlakuan pemberian pupuk taspu dan hormon tanaman unggul terhadap volume akar hal ini dikarenakan dengan dikombinasikannya pupuk taspu dan hormon tanaman unggul pada dosis yang tepat telah dapat memberikan respon yang baik terhadap pertumbuhan tanaman anthurium sehingga akar yang terbentuk akan lebih banyak dengan demikian volume akarnya akan meningkat. Pupuk taspu merupakan bahan organik yang dapat memperbaiki kondisi tanah menjadi lebih subur, sehingga unsur hara dalam tanah akan lebih tersedia, selain itu dengan pemberian bahan organik akan lebih dapat mengaktifkan mikroorganisme dalam tanah.

Tandan kosong kelapa sawit dapat dimanfaatkan sebagai sumber pupuk organik yang memiliki kandungan unsur hara yang dibutuhkan oleh tanah dan tanaman. Tandan kosong kelapa sawit mencapai $23 \%$ dari jumlah pemanfaatan limbah kelapa sawit tersebut memberikan manfaat lain dari sisi ekonomi. Keunggulan kompos tandan kosong kelapa sawit meliputi: kandungan kalium yang tinggi, tanpa penambahan starter dan bahankimia, memperkaya unsur hara yang ada di dalam tanah, dan mampu memperbaiki sifat fisik, kimia dan biologi (Hayat dkk, 2014).

Karjadi dan Buckhori (2008) mengemukakan bahwa zat pengatur tumbuh yang paling berperan pada proses pemanjangan akar adalah auksin yang berfungsi mengatur sintesis RNA dan mengkonsentrasikannya pada meristem belakang apical akar yang merupakan pusat zona pembelahan dan pemanjangan. Disini sel-sel akar akan memanjang dengan mendorong ujung akar termasuk meristem. Dengan kadar pemberian hormon auksin yang tepat dapat meningkatkan pemanjangan pada sel-sel ujung akar secara maksimal, namun pemberian yang tidak tepat menyebabkan hormon auksin tidak memberikan pemgaruh apapun

Hormon tanaman unggul mempunyai kadar kandungan pupuk : N 63 ppm, Mg $0.01 \mathrm{ppm}, \mathrm{Zn} 0.01 \mathrm{ppm}, \mathrm{P} 6 \mathrm{ppm}, \mathrm{Cu} 0.05$ ppm, Co 0.01 ppm, K 14 ppm, Na 0.22 ppm, Fe 0.68 ppm, selain itu hormon tanaman unggul juga memiliki kandungan bahan aktif yaitu : asam Giberela (Ga3, Ga5, Ga7) 0.383 g/l, Asam Asetik Indol 0.156 g/l, Zeatin 0.106 g/l (Prana, 2009). Cara aplikasi hormon tanaman unggul yaitu dengan cara penyemprotan dengan pengkabutan, waktu aplikasi yang tepat yaitu pada pagi atau sore hari, karena pada saat itulah membukanya stomata atau mulut daun (Sujimin, 2009). 


\section{KESIMPULAN DAN SARAN}

\section{Kesimpulan}

1. Interaksi pemberian kompos tandan kosong kelapa sawit (taspu) dan hormon tanaman unggul memberikan pengaruh yang nyata terhadap parameter jumlah daun per tanaman dan volume akar, dengan perlakuan terbaik pemberian kompos tandan kosong kelapa sawit (taspu) $30 \mathrm{~g} /$ tanaman dan hormon tanaman unggul $4 \mathrm{ml} / \mathrm{l}(\mathrm{P} 2 \mathrm{H} 2)$.

2. Pengaruh utama pemberian kompos tandan kosong kelapa sawit (taspu) nyata terhadap semua parameter pengamatan, perlakuan terbaik pada pemberian kompos tandan kosong kelapa sawit (taspu) $30 \mathrm{~g} /$ tanaman (P2)

3. Pengaruh utama hormon tanaman unggul nyata terhadap semua parameter pengamatan yaitu, perlakuan terbaik pada pemberian hormon tanaman unggul $4 \mathrm{ml} / \mathrm{l}$ (H2).

\section{Saran}

Untuk memperoleh pertumbuhan tanaman anthuirium yang lebih baik disarankan untuk menggunakan kompos tandan kosong kelapa sawit (taspu) $30 \mathrm{~g} / \mathrm{tanaman}$ dan hormon tanaman unggul $4 \mathrm{ml} / \mathrm{l}$.

\section{DAFTAR PUSTAKA}

Anggar. $2014 . \quad$ http://www.sawit Indonesia.com/sajian utama/lebih-hijaudengan-pupuk-organik. Diakses tanggal 24 Maret 2015.

Desatiga. 2009. Melipatgandakan hasil pertanian dengan pupuk hantu. http://desatiga.wordpress.com/2009.03/22 /melipatgandakan -hasil-pertaniandengan-pupuk-hantu. Diakses tanggal 20 Maret 2015.

Dwidjoseputro, D. 2002. Pengantar Fisiologi Tumbuhan. Penerbit PT. Gramedia. Jakarta.
Gardner, F.P., Pearce, R.B. dan Mitchell, R.I., 1991. Fisiologi Tanaman Budidaya, Jilid 1, Penerjemah Herawati Susilo, UI Press. Jakarta.

Hayat. E.S. dan Andayani.S. 2014. Pengelolaan Limbah Tandan Kosong Kelapa Sawit Dan Aplikasi Biomassa Chromolaena odorata Terhadap Pertumbuhan Dan Hasil Tanaman Padi Serta Sifat Tanah Sulfaquent. Jurnal Teknologi Pengelolaan Limbah. 17 (2): 44-51.

Harjadi, S.S. 1990. Pengantar Agronomi. Penerbit PT. Gramedia. Jakarta.

Kaderi, H. 2004, Teknik Pengolahan Pupuk Pelet dari Gulma sebagai Pupuk Majemuk dan Pengaruhnya Terhadap Tanaman Padi, Buletin Teknik Pertanian 9 (2): 47-49.

Karjadi. A. K dan Buckhory. A. 2008. Pengaruh Auksin dan Sitokinin Terhadap Pertumbuhan dan Perkembangan Jaringan Meristem Kentang Kultivar Granola. Jurnal Hortikultura 18 (4): 380-384.

Lingga. P. 2005. Petunjuk Penggunaan Pupuk. Penebar Swadaya. Jakarta.

Novizan. 2005. Pertunjukan Pemupukan Yang Efektif. Agro Media Pustaka. Jakarta.

Rosmawaty, T. 2003. Pengaruh Pemberian Batguano dan Primagro Terhadap Pertumbuhan dan Hasil Seledri di Dalam Polybag. Jurnal Dinamika Pertanian. XVII (2): 163.

Sujimin. 2009. Pupuk Hormon Tanaman Unggul. Jawa Tengah. Indonesia.

Prana. W. 2009. Katalog Produk Pupuk Hantu. http://indonetwork.co.id./ tokoherbalindo/1316939/pupuk-organik hantu.htm. Diakses pada tanggal 23 Maret 2015. 
